\title{
Dietary Knowledge, Behaviours and Attitudes of Students of Public School in a Northeastern City in Brazil
}

\author{
Marize Melo dos Santos ${ }^{1,2 *}$, Adriana de Azevedo Paiva1,2, José Ivo dos Santos Pedrosa1,3, \\ Rosângela Lopes Viana ${ }^{1,2}$ \\ ${ }^{1}$ Federal University of Piaui, Campus Universitario Ministro Petronio Portella, Teresina, Brasil \\ ${ }^{2}$ Department of Nutrition, Postgraduate Program in Food and Nutrition, Federal University of Piaui, Teresina, Brazil \\ ${ }^{3}$ Department of Community Medicine, Federal University of Piaui, Teresina, Brazil \\ Email: ${ }^{*}$ marizesantos@ufpi.edu.br
}

Received 9 April 2014; revised 13 May 2014; accepted 21 May 2014

Copyright (C) 2014 by authors and Scientific Research Publishing Inc.

This work is licensed under the Creative Commons Attribution International License (CC BY).

http://creativecommons.org/licenses/by/4.0/

c) (i) Open Access

\begin{abstract}
This quasi-experimental intervention was conducted with 10- to 14-year-old students enrolled in public schools in Teresina, Brazil, to evaluate the effects of a nutritional education program on the students' knowledge, behaviour and attitudes towards nutrition. The dietary attitudes were evaluated in terms of food tastes/preferences and food behaviours. The participants in the study included 126 students from four schools. Differences between before and after the intervention were found regarding knowledge about the "food pyramid", "healthy eating" and "nutrients" ( $p$ $0.05)$. There was reduction from $35 \%$ to $18.2 \%(p=0.029)$ in the preference for unhealthy foods, such as greasy meats and processed foods. The students reported changes in their dietary behaviour in response to the intervention $(p<0.05)$. The educational model used in this study was shown to be effective for modifying the food and nutritional knowledge levels of the students and the associated dietary attitudes and practices.
\end{abstract}

\section{Keywords}

Intervention Studies, Dietary Behaviours, Attitude, Students

\section{Introduction}

A positive correlation between education and health has been shown by research in several fields and scientific

\footnotetext{
${ }^{*}$ Corresponding author.
}

How to cite this paper: Santos, M.M. dos, Paiva, A.de A., Pedrosa, J.I.dos S. and Viana, R.L. (2014) Dietary Knowledge, Behaviours and Attitudes of Students of Public School in a Northeastern City in Brazil. Health, 6, 1315-1321. 
subjects [1]. According to Kremser [2], the concept of schools that promote health indicates changes in the traditional forms of health education and in the physical and social environments. Programs that act effectively in the school context enable students to make choices and define behaviours that promote health by improving their food and nutrition knowledge, behaviours, attitudes and other abilities. These improvements are then reflected in the family environment and the community [3].

Adolescence is subject to cultural, social and environmental influences that are reflected in dietary habits. This age group is associated with a dietary profile in which a lower consumption of beans, salads and vegetables in general is common, along with a higher consumption of sweets, sodas, pizza and fried and baked snacks. In general, these patterns are related to family income [4].

This dietary behaviour indicates a troublesome epidemiologic profile. It is estimated that approximately $70 \%$ of Brazilian people will be overweight in 20 years; therefore, it is urgent to implement actions to control and prevent weight gain [4].

According to Brazil's National Policy for Alimentation and Nutrition, the "promotion of adequate and healthy nutrition must transcend the limits of the health system and must be inserted into other social settings, such as community spaces for physical activity, schools and day care centres, community associations, social assistance networks and work environments, among others" [4]. There is a consensus that, upon admission to school, children are subject to influences, especially on food choices, when they begin to socialise with other people and develop other social habits. Thus, schools impact not only education but also the knowledge and practices that promote health education and encourage healthy dietary habits for families and communities to promote the development of healthy attitudes [5].

Based on these principles, a food and nutrition educational program was developed to improve knowledge about healthy eating and behaviours related to eating. The present study evaluated the effects of this program on the behaviours and dietary attitudes of middle school students in public schools.

This study will contribute relevant information on the subject in scientific literature which according to Ramos, et al. [6] in a recent review found a lack of theoretical and methodological references in the school context to support the practices of food and nutritional education of the group in question.

\section{Materials and Methods}

This study assessed male and female adolescents between 10 and 14 years of age who were enrolled in public schools and a program to assist the youth from families with low income in Teresina, a city in northeastern Brazil, from 2011 to 2012.

\subsection{Sample Definition}

The study sample was chosen randomly by the following steps: 1) the conglomerates comprised 302 registered schools in the district zones of the North (70), South (95), East (84) and Southeast (53); 2) the North district zone was randomly chosen; 3) from a conglomerate that had 28 schools with students in the age group of the study population, 4 schools were randomly chosen; 4) a single grade in each school that had an average of 25 students was chosen through a raffle; and 5) intervention groups with a maximum of 15 students were formed.

\subsection{Intervention Design}

The protocol consisted of a quasi-experimental intervention that enabled "before and after" comparisons. The syllabus was composed of three specific themes (knowledge, hygiene and food preparation) distributed over nine educational sessions. The sessions were conducted once per week by scientific initiation scholars from the Nutrition Department of the Federal University of Piaui under the supervision of nutritionists (professors and project coordinators).

The intervention was based on problem-based education proposed by Paulo Freire [7] which is open to knowledge and change. According to the educator, "teaching requires the conviction that change is possible..." thus, each topic was contextualized in the students' daily diet.

\subsection{Standardisation of Pedagogical Techniques}

To standardise the pedagogical techniques, the manual "school nutrition: planning of educational actions" [8] 
was prepared by field staff, modified to make the application of the educational interventions easier and more unified.

The themes included the following subjects:

Theme I-Getting to know food

Strategy A: To be or not to be: vegetable or animal?

Strategy B: Knowledge mixture: natural and processed food

Strategy C: Healthy foods: the food pyramid and portion sizes

Theme II-Food safety

Strategy A: Why be careful with food?

Strategy B: Watch out for food hazards!

Strategy C: Hygiene moments

Theme III-Preparing food

Strategy: Magic hands: the joy of eating; nutritional recipes I, II and III

Healthy dietary practices were encouraged during the educational sessions, beginning with pedagogic participative strategies involving dialogue description of contents, puppetry, group dynamics as interactive games, simulation of food shopping, hand hygiene, thematic workshops, play eating in restaurants, preparing healthy food for lunchboxes and food preparation followed by sampling. The main resource used during the classes was the Brazilian food pyramid, which emphasises the importance of consuming the appropriate quality and quantity of foods.

This pedagogical strategy facilitated the students' understanding of the nutritional value of foods based on their food universe. From this dialog, key questions in each topic developed were constructed.

Familiar and unfamiliar snacks, such as fruits, greens, vegetables, whole-grain, dairy products, breads and other foods, were offered during the educational intervention to encourage consumption.

The teaching strategies were planned with the idea of promoting the development of students' autonomy in relation to their daily and future eating habits. In this sense, Marcolino and Santos [9] describe the health educator as someone who should eliminate hierarchy and join the student in order to build a new construction based on knowledge and experience of both parties.

\subsection{Evaluation Design}

Two types of evaluation were adopted: a baseline diagnostic evaluation to identify differences and/or changes related to the intervention and a final evaluation to assess the efficacy of the intervention.

The assessment of learning was based on the percentage of comprehension of the educational content, according to the criteria for approval adopted by the Teresina education board. Satisfactory learning was considered to be comprehension by $\geq 60 \%$ of the students, and unsatisfactory learning was considered to be comprehension by $<60 \%$ of the students.

The dietary attitudes of the students were evaluated in terms of their reported food tastes and preferences, as well as their food behaviours in terms of daily and weekly consumption. This evaluation was based on the Alimentary Guide for the Brazilian Population [10].

\subsection{Data Collection}

The data were collected by the study personnel, including scientists and undergraduate nutrition students, using interviews and structured questionnaires. The data collection was supervised by the nutrition professors.

Before their administration, the questionnaires were tested, and the study personnel were trained their implementation. After nine sequential weekly meetings, the questionnaires were re-administered.

\subsection{Ethical Aspects}

The study was approved by the Ethics Committee of Federal University Piaui (no. 0076.0.045.000-11, of 16/05/ 11). The students' parents or guardians were informed about the study in meetings convened at each school. Thorough and clear explanations regarding the research objectives, the types of activities addressed in the study and the importance and benefits of the project were provided. The parents then were invited to sign a Free Informed Term of Consent (FITC) form drafted in accordance with the regulatory guidelines for research involving human beings (Resolution Ministry of Health, National Health Council, Brazil—Resolution no. 196, dated 
10/10/1996).

\subsection{Statistical Analysis}

The data were analysed using software SPSS v. 17.0 (SPSS Inc., Chicago, IL, USA). Descriptive statistics were used to determine the frequency of the occurrence of each event. The relationships among the variables were verified through a chi-squared test $\left(\chi^{2}\right)$. A level of statistical significance of $\mathrm{p}<0.05$ was applied to all the tests in the study.

\section{Results}

In total, 126 students enrolled in 4 schools participated in the study. One of the schools was located in a rural area, and the other three were in urban areas. The student gender distribution was approximately equal among the four schools, with a slightly higher percentage of males (53.5\%).

The students had an almost $100 \%$ attendance rate for the nine educational sessions (with an average attendance of eight sessions), which highlights the students' interest in the themes covered during the program. When an absence occurred, the student was provided with a review of the missed material at the following class.

There were significant increases in the level of knowledge about the "food pyramid", "healthy diet" and "nutrients" after the intervention. The proportion of students who were unfamiliar with the food pyramid was reduced from $92.4 \%$ to $58 \%$, and the percentages of those who were ignorant about concepts of healthy eating and nutrients were reduced from $60 \%$ to $42.9 \%$ and $79 \%$ to $50.4 \%$, respectively, at the end of the intervention, Figure 1.

The students expressed their preference or dislike for foods that are considered unhealthy. There was a significant reduction in the degree of preference for unhealthy food, such as greasy meats and processed foods, from approximately $35 \%$ to $18.2 \%(\mathrm{p}=0.029)$, Table 1 .

The proportion of students who reported substituting snacks for main meals was reduced from $21.5 \%$ to $9.1 \%$ after the intervention $(p=0.005)$, and the proportion of students who reported a preference for sweets, candies and cakes was reduced by $16.6 \%$.

The analysis of the students' dietary behaviours revealed changes in response to the intervention. For example, the "consumption of fried foods and packaged snacks" "four times or more" per week was reduced from $43 \%$ before the intervention to $19.8 \%$ afterwards $(\mathrm{p}<0.001)$, Table 2 .

There were significant improvements related to the variables "consumption of sweets per week" and "consumption of soda or artificial juice". The percentage of students who reported consuming these foods four or more times per week was reduced from $44.4 \%$ to $30.2 \%(\mathrm{p}=0.008)$ for sweets and from $55.6 \%$ to $37.3 \%(\mathrm{p}=$ 0.007 ) for soda and artificial juice, Table 2.

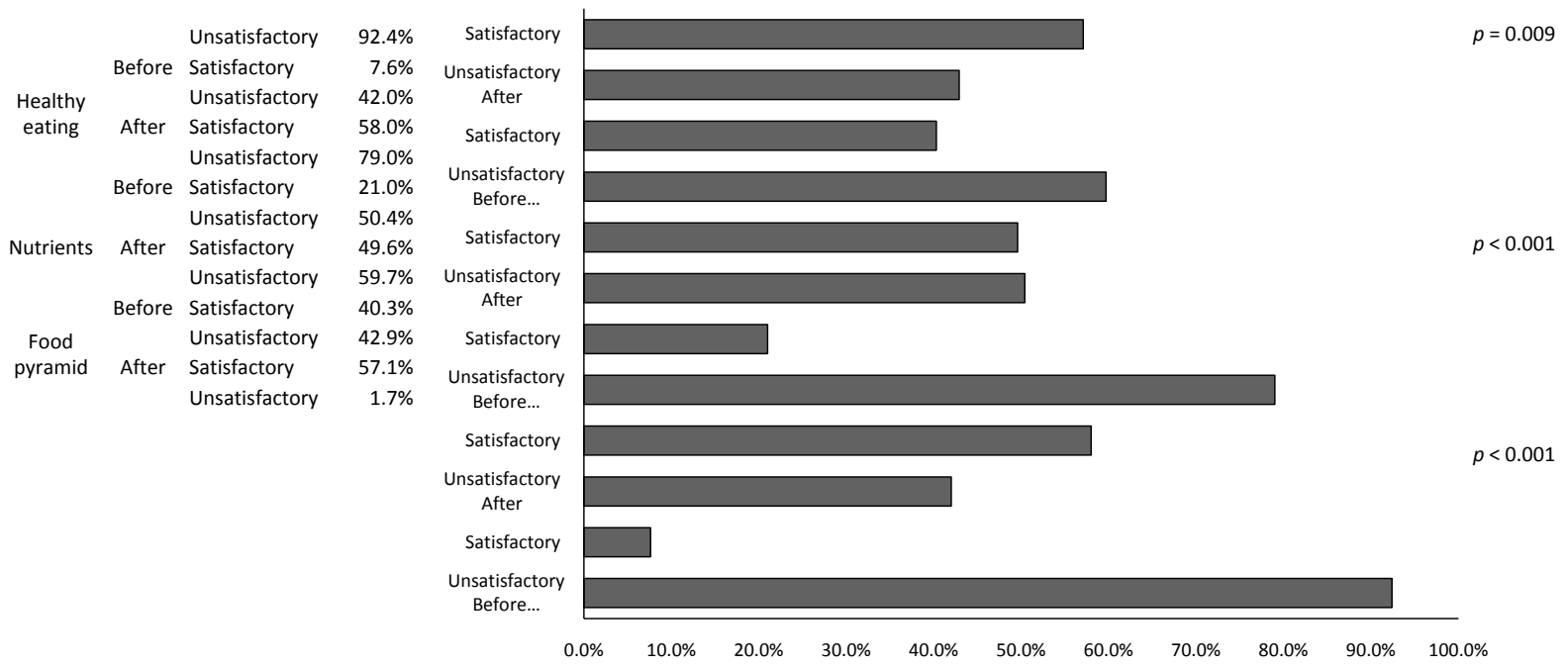

Figure 1. Knowledge about alimentation and nutrition of students from municipal schools in Teresina, before and after educative intervention. Teresina, Piauí, Brasil, 2012 ( $\mathrm{N}=119)$. 
Table 1. Attitudes about alimentation of students from municipal schools in Teresina, before and after educative intervention. Teresina, Piauí, Brasil, 2012 ( $\mathrm{N}=121)$.

\begin{tabular}{|c|c|c|c|}
\hline \multirow{2}{*}{ Variables } & Before EI & \multirow{2}{*}{$\begin{array}{c}\text { After EI } \\
\text { n (\%) }\end{array}$} & \\
\hline & n (\%) & & \\
\hline \multicolumn{4}{|c|}{ In eating times, do you prefer greasy meat and processed food? } \\
\hline Yes, I do & $25(20.7)$ & $34(28.1)$ & \multirow{4}{*}{$\begin{array}{l}x^{2}=9.04 \\
p=0.029\end{array}$} \\
\hline Sometimes I do & 49 (40.5) & $61(50.4)$ & \\
\hline I have no preference & $05(4.1)$ & $04(3.3)$ & \\
\hline I don't prefer & $42(34.7)$ & $22(18.2)$ & \\
\hline \multicolumn{4}{|c|}{ If you could switch your meals for snacks } \\
\hline I wouldn’t & $76(62.8)$ & $76(62.8)$ & \multirow{4}{*}{$\begin{array}{l}x^{2}=12.89 \\
p=0.005\end{array}$} \\
\hline Maybe I would & $11(9.1)$ & $27(22.3)$ & \\
\hline I don't know & $08(6.6)$ & $07(5.8)$ & \\
\hline Yes, I would & $26(21.5)$ & $11(9.1)$ & \\
\hline \multicolumn{4}{|c|}{ During the day do you prefer to eat sweets, candies, cakes? } \\
\hline I don’t & $16(13.2)$ & $33(27.3)$ & \multirow{4}{*}{$\begin{array}{c}x^{2}=12.74 \\
p=0.005\end{array}$} \\
\hline Sometimes I do & $62(51.2)$ & 64 (52.9) & \\
\hline I don't know & $03(2.5)$ & $04(3.3)$ & \\
\hline I always prefer them & 40 (33.1) & $20(16.5)$ & \\
\hline
\end{tabular}

$\mathrm{EI}=$ Educative Intervention.

Table 2. Alimentary behavior of students from municipal schools in Teresina, before and after educative intervention. Teresina, Piauí, Brasil, 2012 ( $\mathrm{N}=126)$.

\begin{tabular}{|c|c|c|c|}
\hline \multirow{2}{*}{ Variable } & Before the EI & After the EI & \\
\hline & n (\%) & n (\%) & \\
\hline \multicolumn{4}{|c|}{ How many times a week do you eat processeded food such as baloney and sausage? } \\
\hline Up to two & 49 (38.9) & $67(53.2)$ & $x^{2}=5.25$ \\
\hline Three & $36(28.6)$ & $29(23.0)$ & \multirow[t]{2}{*}{$\mathrm{p}=0.072$} \\
\hline Four or more & $41(32.5)$ & $30(23.8)$ & \\
\hline \multicolumn{4}{|c|}{ How many times a week do you eat sweets (cakes, candies, ice cream)? } \\
\hline Up to two & $39(31.0)$ & $63(50.0)$ & $x^{2}=9.74$ \\
\hline Three & $31(24.6)$ & 25 (18.9) & \multirow[t]{2}{*}{$\mathrm{p}=0.008$} \\
\hline Four or more & $56(44.4)$ & $38(30.2)$ & \\
\hline \multicolumn{4}{|c|}{ How many times a week do you eat fried food, package snacks? } \\
\hline Up to two & $43(34.1)$ & $62(49.2)$ & \multirow{3}{*}{$\begin{array}{c}x^{2}=15.55 \\
p<0.001\end{array}$} \\
\hline Three & $29(23.0)$ & $39(31.0)$ & \\
\hline Four or more & $54(42.9)$ & 25 (19.8) & \\
\hline \multicolumn{4}{|c|}{ How many times a week do you drink soda or artificial juice (package or carton)? } \\
\hline Up to two & 25 (19.8) & $44(34.9)$ & $x^{2}=9.10$ \\
\hline Three & $31(24.6)$ & $35(27.8)$ & \multirow[t]{2}{*}{$\mathrm{p}=0.007$} \\
\hline Four or more & $70(55.6)$ & 47 (37.3) & \\
\hline \multicolumn{4}{|c|}{ Do you regularly substitute snacks for breakfast, lunch or dinner? } \\
\hline Yes & $18(14.3)$ & 15 (11.9) & \multirow{3}{*}{$\begin{array}{l}x^{2}=2.03 \\
p=0.362\end{array}$} \\
\hline No & $71(56.3)$ & $82(65.1)$ & \\
\hline Sometimes & 37 (29.4) & $29(23.0)$ & \\
\hline
\end{tabular}

$\mathrm{EI}=$ Educative Intervention. 


\section{Discussion}

The fundamental role of health promotion policies is to assist individuals with decision making, allowing them to acquire a higher degree of choice in society by increasing their knowledge and rights [11].

Building on this idea, the present study evaluated changes in attitudes and dietary behaviours in response to a nutritional education program for middle school students.

Poulain et al. [12] have described an attitude as "a group of individual predispositions in relation to an object or practice". In this sense, the students in this study expressed their preference or dislike for foods that are considered unhealthy. Understanding the importance of a healthy diet had an impact on the attitudes of the students and, consequently, the dietary behaviours related to those attitudes.

Previous interventions with methodological designs similar to those of the present work have produced excellent results. In a study of 25 students (boys and girls 7 to 10 years of age), González and Wichmann [13] showed that before a five-month educational intervention, the percentage of students with deficient knowledge was $40 \%$, and the percentage with adequate knowledge was $60 \%$. After the intervention, the percentage of students with deficient knowledge was reduced from $16 \%$ to $24 \%$, and the percentage with adequate knowledge increased from $16 \%$ to $76 \%$ ( $\leq 0.001)$.

In a study involving 951 students from preschool to the $8^{\text {th }}$ grade (6 to 16 years of age, 471 males and 487 females), a significant increase ( $<0.05)$ in the level of knowledge about food and nutrition was observed following a 6-month dietary education programme [14].

The highest rates of ingestion of sugars and sweets, fried foods and packaged snacks by the students in the present work were similar to the rates reported for students in the private and public school systems of Sao Luiz, Maranhao, Northeastern Brazil [15], and for adolescents in Teixeira de Freitas, Bahia, Northeastern Brazil [11]. These findings are related to the frequent availability and consumption of these types of foods, along with sodas and artificial juices, at schools. The rates of consumption of these unhealthy foods increased when such snacks were substituted for main meals, a common practice according to the results of these studies.

Factors such as fads, advertisements, the influence of peers and disagreement with family and social values contribute significantly to the ability of children and adolescents to change their eating habits and consume appropriate snacks [16]. Moreover, a preference for snacks, tartlets, pizza, chips, sodas and cakes has been observed in studies involving students from developed countries and from Brazil [17].

The number of meals that adolescents consume is influenced by traditions; by the social, economic and educational level of the family; and even by the media [18]. One positive result of the present study was that the majority of the participants consumed more than three daily meals, with small breaks in between the meals. An inadequate distribution of the diet throughout the day and an irregular eating schedule can cause problems related to prolonged fasting, such as a higher propensity for gastritis or the consumption of excessively heavy meals to "compensate" for earlier fasting [19].

\section{Conclusions}

The educational model used in this study was shown to be an effective strategy for modifying the participating adolescents' knowledge about diet and nutrition, as reflected by the changes in their attitudes and eating practices.

These results reinforce the importance of similar actions for improving the diets and nutrition of children and adolescents in preschools and in both private and public schools to allow them to achieve healthier lifestyles throughout their lives.

\section{Financial Support}

International Life Sciences Institute, Brazil (ILSI-BRASIL).

\section{References}

[1] Albert, C. and Davia, M.A. (2011) Education Is a Key Determinant of Health in Europe: A Comparative Analysis of 11 Countries. Health Promotion International, 26, 163-170. http://dx.doi.org/10.1093/heapro/daq059

[2] Kremser, W. (2011) Phases of School Health Promotion Implementation through the Len of Complexity Theory: Lessons Learnt from an Austria Case Study. Health Promotion International, 26, 136-147. 
http://dx.doi.org/10.1093/heapro/daq063

[3] Triches, R.M. and Giugliani, E.R.J. (2005) Obesidade, práticas alimentares e conhecimentos de nutrição em escolares. Revista de Saúde Publica, 39, 541-547. http://dx.doi.org/10.1590/S0034-89102005000400004

[4] Brazilian Ministry of Health (2012) National Policy on Food and Nutrition. Brazilian Ministry of Health, Brazil, 84.

[5] Brazilian Ministry of Health (2008) National Policy on Food and Nutrition. Brazilian Ministry of Health, Brazil, 15.

[6] Ramos, F.P., Santos, L.A.S. and Reis, A.B.R. (2013) Educação alimentar e nutricional em escolares: Uma revisão de literatura. Cadernos de Saúde Pública, 29, 2147-2161. http://dx.doi.org/10.1590/0102-311x00170112

[7] Freire, P. (1996) Pedagogia da autonomia: Saberes e práticas necessários à prática educativa. Paz e Terra, São Paulo, 148.

[8] Silva, F.N., Oliveira and Santos, M.M. (2011) Alimentação escolar: Planejamento de ações educativas. www.ufpi.br/ppgan/fichacatalográfica

[9] Marcolino, F.F. and Santos, I.G. (2007) Grupos educativos: Uma estratégia de educação em saúde. In: Santos, I.G., Org., Nutrição: Da assistência à promoção da saúde, RCN Editora, São Paulo, 101-104.

[10] Brazilian Ministry of Health (2006) National Policy on Food and Nutrition. Brazilian Ministry of Health, Brazil, 210.

[11] Santos, J.S., Costa, C.O.M., Sobrinho, C.L.N., Silva, M.C.M. and Souza, K.E.P. (2005) Perfil antropométrico e consumo alimentar de adolescentes de Teixeira de Freitas, Bahia. Revista de Nutrição, 18, 623-632. http://dx.doi.org/10.1590/S1415-52732005000500005

[12] Poulain, J.P., Proença, R.P.C. and Diez-Garcia, R.W. (2011) Diagnóstico das práticas e comportamento alimentar: Aspectos metodológicos. In: Diez-Garcia, R.W. and Cervato-Mancuso, A.M., Eds., Mudanças Alimentares e Educação Nutricional, Guanabara Koogan, Rio de Janeiro, 149-163.

[13] González, A.P.H. and Wichmann, F.M.A. (2012) Consumo alimentar e conhecimentos em nutrição de escolares submetidos a oficinas de intervenção nutricional. http://www.crn2.org.br/pdf/artigos/artigos1277239551.pdf

[14] Deminice, R., Laus, M.F., Marins, T.M., Silveira, S.D.O. and Oliveira, J.E.D. (2007) Impacto de um programa de educação alimentar sobre conhecimentos, práticas alimentares e estado nutricional de escolares. Alimentação e Nutrição Araraquara, 18, 35-40.

[15] Conceição, S.I.O., Santos, C.J.N. and Silva, S.S.M. (2010) Consumo alimentar de escolares das redes pública e privada de São Luis, Maranhão. Revista de Nutrição, 23, 993-1004. http://dx.doi.org/10.1590/S1415-52732010000600006

[16] Gambardella, A.M.D., Frutuoso, M.F.P. and Franchi, C. (1999) Prática alimentar de adolescentes. Revista de Nutrição, 12, 55-63. http://dx.doi.org/10.1590/S1415-52731999000100005

[17] Garcia, G.C.B., Gambardella, A.M.D. and Frutuoso, M.F.P. (2003) Estado nutricional e consumo alimentar de adolescentes de um centro de juventude da cidade de São Paulo. Revista de Nutrição, 16, 41-50. http://dx.doi.org/10.1590/S1415-52732003000100005

[18] Silva, J.G., Teixeira, M.L.O. and Ferreira, M.A. (2012) Alimentação e saúde: Sentidos atribuídos por Adolescentes. Escola Anna Nery, 16, 88-95. http://dx.doi.org/10.1590/S1414-81452012000100012

[19] Campana, E.M.G., Brandão, A.A., Pozzan, R., França, M.R. and Fonseca, F.L. (2009) Pressão arterial em jovens como marcador de risco cardiovascular: Estudo do Rio de Janeiro. Arquivos Brasileiros de Cardiologia, 93, 657-665. http://dx.doi.org/10.1590/S0066-782X2009001200016 